\title{
STRUCTURAL FEATURES OF CULTURAL LANDSCAPE IN THE KARST AREA (LANDSCAPE IN TRANSITION)
}

\author{
STRUKTURNE IN OBLIKOVNE ZNAČILNOSTI KRAŠKE \\ KULTURNE KRAJINE (POKRAJINA V PREOBRAZBI)
}

BRANKA ANIČIĆ ${ }^{1} \&$ DRAŽEN PERICA²

\footnotetext{
${ }^{1}$ Department of Landscape Architecture, Faculty of Agriculture, University of Zagreb, Svetošimunska 25, ZAGREB, CROATIA

${ }^{2}$ Geographical Department, Faculty of Science, University of Zagreb, Marulićev trg 19/II, ZAGREB, CROATIA
} 


\section{Branka Aničić \& Dražen Perica: Structural Features of Cultural Landscape in the Karst Area (land- scape in transition)}

During a long historical continuity in the karst area a specific landscape type has evolved due to varied climatic, geomorphological, topographic as well as socio-economic conditions. This is characterized by great typological diversity based on authentic features both of natural and cultural origin. These have occurred as a consequence of balanced economic land-uses from early periods on. The main quality of these landscapes is derived from unique agricultural land-use patterns, which constitute one of the most valuable spatial heritages in the entire Mediterranean. However, the recent evolution, mainly in the socio-economic sphere, generated far-reaching impacts in the rural areas which largely affect the integrity and traditional harmony the karst countryside in general and the landscape in particular. The basic intention of the paper is to outline these transformations as a serious threat and immense loss of the national cultural heritage and to emphasize the great responsibility of this generation in these processes.

Key words: Mediterranean Karst area, agricultural land-use patterns, cultural heritage, cultural landscape, Dinaric karst, Croatia.

\section{Izvleček}

UDK: 911.53:551.44(262)

\section{Branka Aničić \& Dražen Perica: Strukturne in oblikovne značilnosti kraške kulturne krajine (pokrajina v preobrazbi)}

Na območju krasa se je v dolgi zgodovinski kontinuiteti razvil svojevrsten krajinski tip, kar je pripisati raznovrstnim podnebnim, geomorfološkim, topografskim kot tudi družbeno-gospodarskim razmeram. To zvrst označuje velika tipološka raznolikost, ki sloni na avtentičnih značilnostih naravnega in kulturnega izvora, nastala pa je kot nasledek uravnotežene gospodarske rabe tal od zgodnjih obdobij dalje. Glavna kvaliteta kraških krajin izvira iz edinstvenih vzorcev rabe prostora, ki pomenijo eno najvrednejših prostorskih dediščin v celotnem Sredozemlju. Toda novejši razvoj, predvsem v družbenogospodarski sferi, je izzval daljnosežne posledice na podeželju, kar močno prizadeva celovitost in tradicionalno skladnost krasa nasploh in njegovih pokrajin posebej. Temeljni namen prispevka je orisati to preobrazbo kot resno grožnjo in veliko izgubo nacionalne kulturne dediščine ter podčrtati odgovornost naše generacije $\mathrm{v}$ teh procesih.

Ključne besede: mediteranski kras, vzorci agrarne rabe, kulturna krajina, kulturna dediščina, Dinarski kras, Hrvaška. 


\section{INTRODUCTION}

In the peculiar world of Mediterranean basin, a particular type of karst landscape has developed as a result of long-lasting, balanced economic use of space, with distinguishable agricultural peculiarities: terraced landscapes, vineyards, olive groves, orchards, vegetable gardens, usually interlaced by various dry-wall structures.

Our inherited karst cultural landscape, evolving through historical continuity under the influence of traditional agriculture developing in Mediterranean conditions, has become a regional landscape of unique identity and importance (Gams 1993). It is characterised by vast typological variations and authenticity of both natural and cultivated landscape structures, which makes a distinctive element of formation of the human environment. As a bearer of the original, karst agricultural landscape embodies the peculiarities of a cultural landscape, which makes it one of the most valuable heritage types in the Mediterranean. Certain rare landscape sites bear witness to our cultural heritage, and knowledge of real value of these places is still lacking.

Due to their characteristics, these places are rather vulnerable and endangered, undergoing changes and expecting new ones, resulting from foreign investment inflow, accelerated tourist development, new infrastructure, especially main traffic arteries, etc. However, their decay and disappearance is not inevitable. The solution lies in finding an interest in preserving and protecting some of these through special economic policy, and the most exquisite ones of them through the category of monuments. It is also necessary to establish that the place has no future unless the physical planning strategy guarantees its economic safety. This paper therefore aims to stress the evident changes, and the need for systematic research of karst cultural landscape, which would lay grounds for landscape evaluation and the defining of relevant protection instruments and categories.

\section{STRUCTURAL FEATURES OF KARST LANDSCAPE}

"The phenomenon of karst lies in the richness of its formations, the contrast of simple, bare ground against the multitude of unexpected forms, and the difference between large dimensions and tiny details which testify to the longevity of its evolution by its very existence" were the words of Dr Božičević, the author of a book (1992) describing natural structural and formal features of Dinaric karst. The most significant natural features of karst are numerous labyrinths of stony peaks, deeply furrowed canyons and gorges, marine bays, pits and abysses, underground holes, cracks in limestone, sinkholes, dolinas and valleys. These diverse relief patterns were used and modified by man to the best of his abilities, thus creating new structures and forms, which brought about even wider diversity of landscape. They emerged from the need for arable land, differing among each other according to the natural conditions, agricultural practices, methods and intensity of soil exploitation, producing various types of cultural karst landscape. Basic land categories created in this area are: grasslands, mainly pastures, vegetable gardens, fields, mixed cultures, orchards, vineyards, forest, barren land, and settlements. Each rural land-use category is distinctive depending on the quantity of stone gathered, and the way of its arrangement. Depth of stone gathering and stone volume was dependent on the purpose, thickness of fertile land and of farming tools. The stones gathered were arranged in drystone walls and heaps, which were con- 
stantly changing and enlarging in parallel with land cultivation activities, thus creating structures that support, intersect and border among arable lands of various shapes and sizes. Depending on their function, they can be: bordering walls (solitary structures) and supporting walls (escarpments), with vast complexity of shapes and methods of stone arrangement, height, texture and width (low, high, narrow, wide, thin, thick, compact, permeable, filled, symmetrical, asymmetric, smooth, rough, dark, etc.) (Gams 1991). Regarding their wide distribution and recognisability, they are the dominant structural element of karst cultural landscape.

Relief features and ways of its exploitation, together with drystone walls, have influenced creation of certain types of karst cultural landscape.

1. One of those is pasture landscape, which exhibits several patterns:

a) open treeless pastureland

b) pastures with scattered trees, providing shade and preventing soil drainage. There is structural diversity even within those categories. In the beginning, pastures required only gathering of fallen stones, which were piled onto bedrock in stone gorges. Later on, with a shift from meat-oriented to milk-oriented animal husbandry, stone gathering was intensified in order to create larger areas of grassland. Stones were heaped into earthless and grassless topographic depressions. At the same time, drystone walls were built to enclose symmetrical and asymmetrical plots of land, to protect grassland and control grazing (Photo. 1).

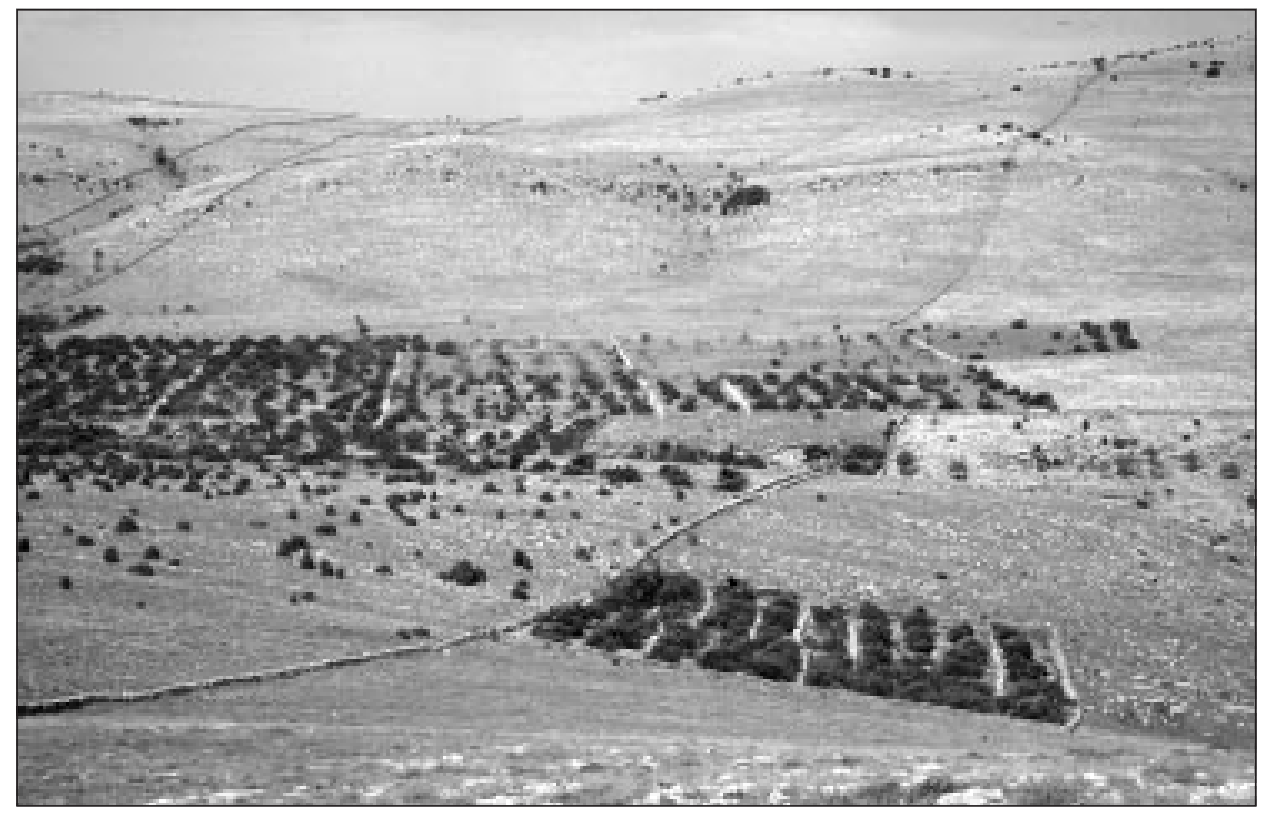

Photo 1: Kornati archipelago. Among the rocks and karst, straight drystone walls (pasture boundaries) and individual olive groves fenced by symmetrical walls contribute to the immense value of the landscape. Disappearance of grazing and growth succession are robbing this area not only of the cultural, but also of its geomorphologic identity (2001). 
Branka Aničić \& Dražen Perica: Structural Features of Cultural Landscape in the Karst Area (landscape in transition)

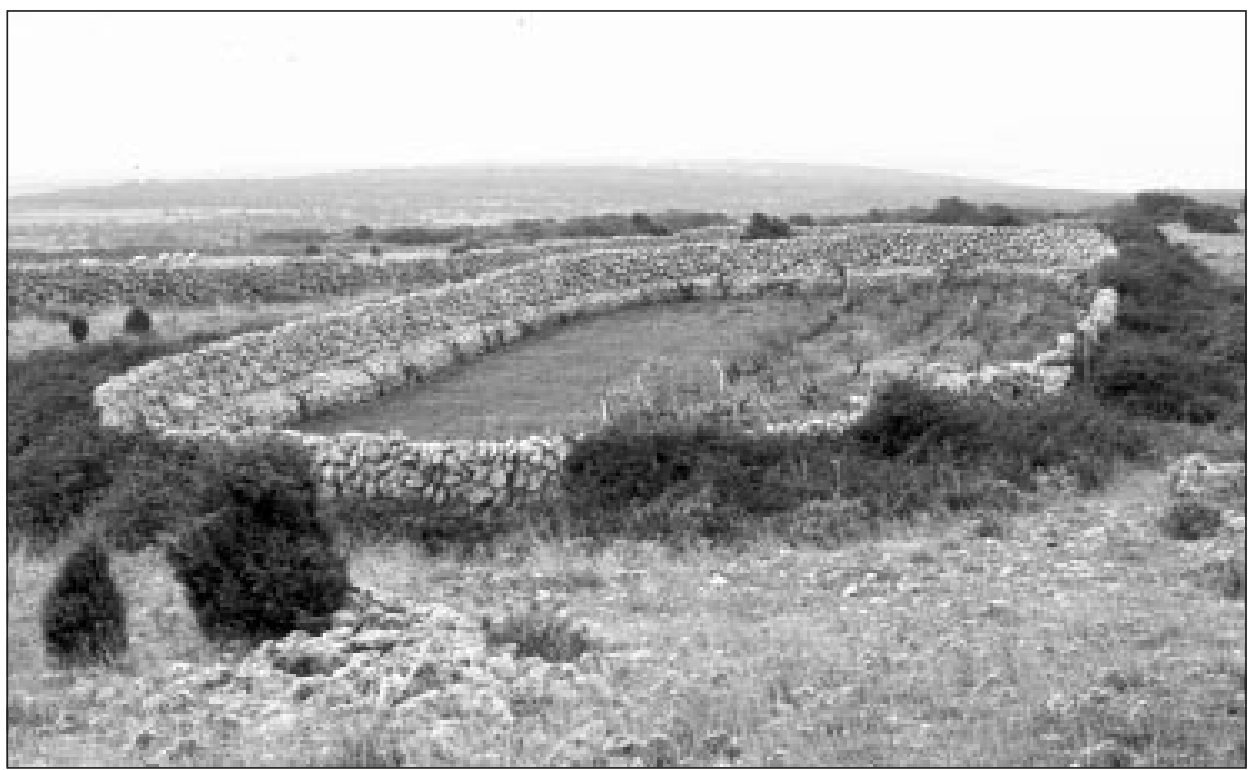

Photo 2: One of the rare preserved arable karst valleys on the island of Krk. It is characteristic for its symmetrical fragmentation of farming plots (1994).

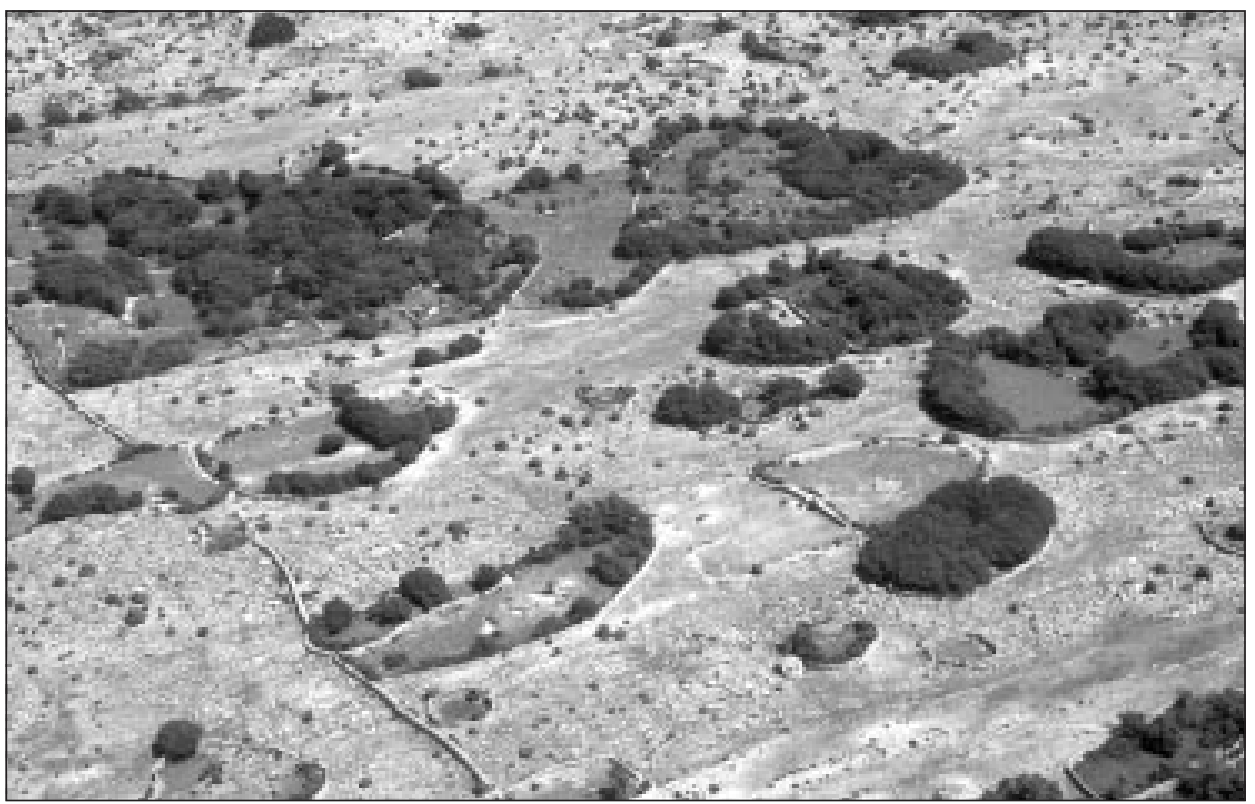

Photo 3: Landscape with sinkholes (cattle folds on Krk). It is found on rocky parts of mild slopes. Poor grassland vegetation has favoured the construction of folds, where cattle were sheltered from sun and bad weather. Today, almost all sinkholes are exposed to overgrowth (2002). 
2. Another type of karst landscape is of sinkholes and karst valleys, with varying widths and depths. These are naturally rounded, funnel-shaped or elongated recesses, of different widths, depths and lengths, with a substantial layer of fertile land. Depending on the purpose and type of drystone wall, there are:

a) enclosed sinkholes and karst valleys, with single-row drystone walls, with oval shapes following the relief forms (Photo. 2). Extraction of stone has resulted in wider grassland areas or homogeneous arable grounds. At higher altitudes there are cattle pens - drmun (enclosed plots with natural vegetation) (Photo. 3 ), whereas at lower altitudes, closer to settlements, these are arable fields (Photo. 4).

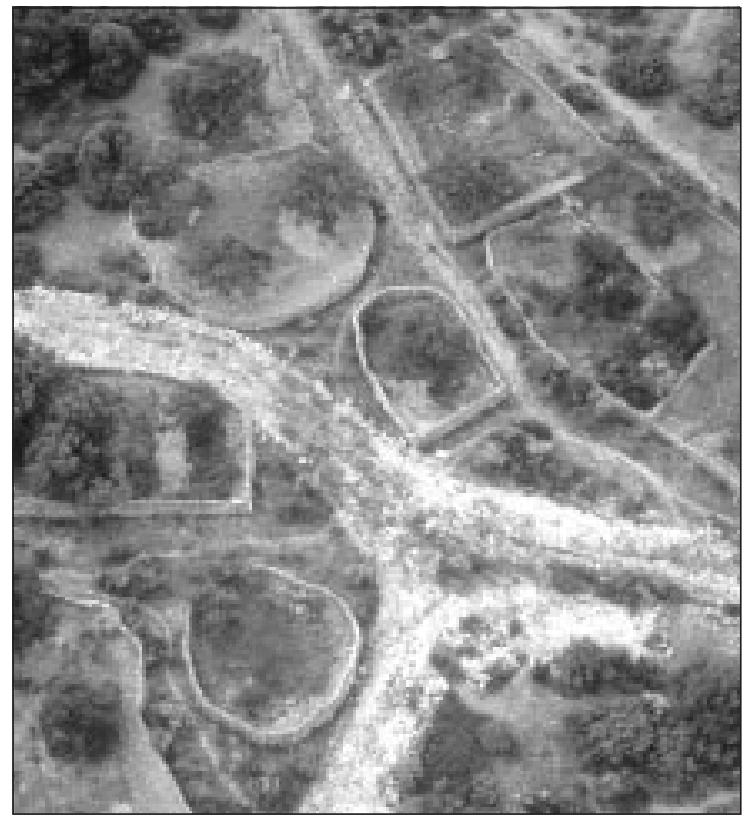

Photo 4: The Trogir surroundings are rich in valuable, picturesque landscape scenes composed of small enclosed and abundant fields.

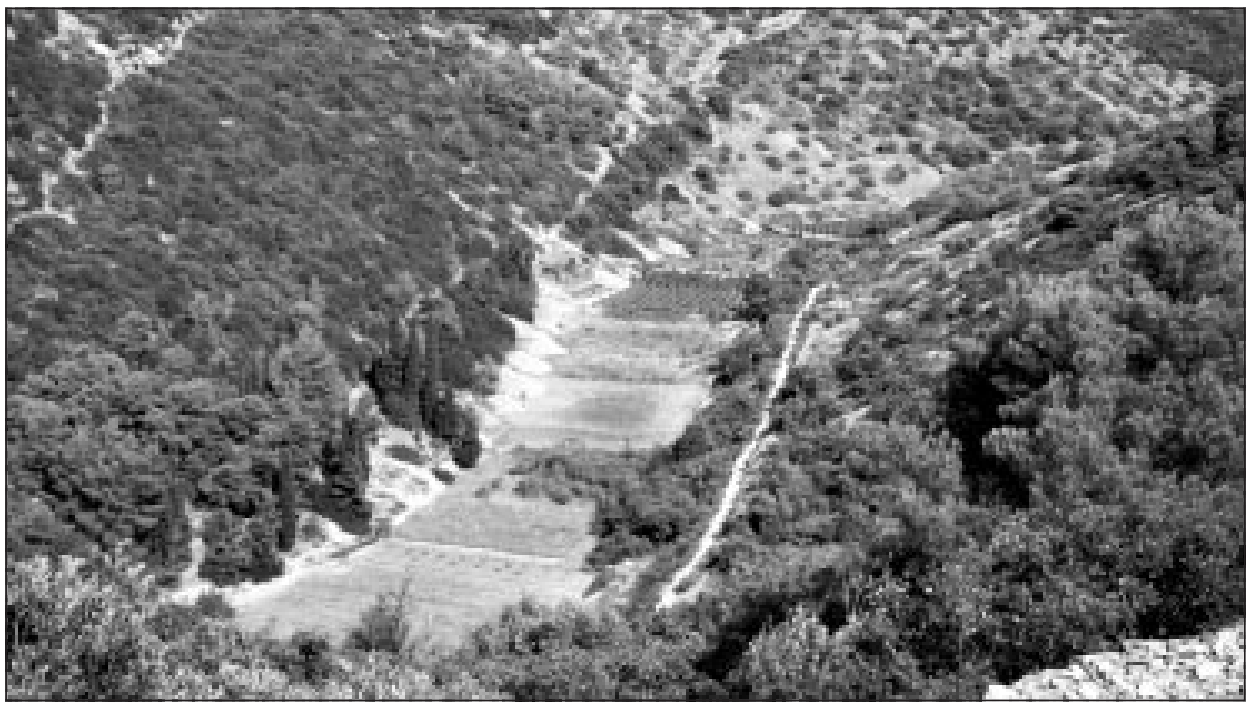

Photo 5: Symmetrical series of karst valleys (Brač). The distribution of valleys is a result of micro-relief forms. Quality soil, the possibilities of its mechanical tillage and easy access, have all enabled revitalisation of most similar valleys (1997). 
b) serial karst valleys - fields in a series, individually enclosed with a single-row drystone wall, located in a valley; they follow its configuration and emerge in various shapes - asymmetric, round, elongated or square plots (Photo. 5).

c) fragmented karst valley - adapted for multi-purpose cultivation. A smooth, straight plot at the bottom was created by gathering stones for pastures or grasslands. On one side of the slope there is usually a field, and on the other several terraces with escarpments (Photo. 6). This type of karst valley is the only one without external walls.

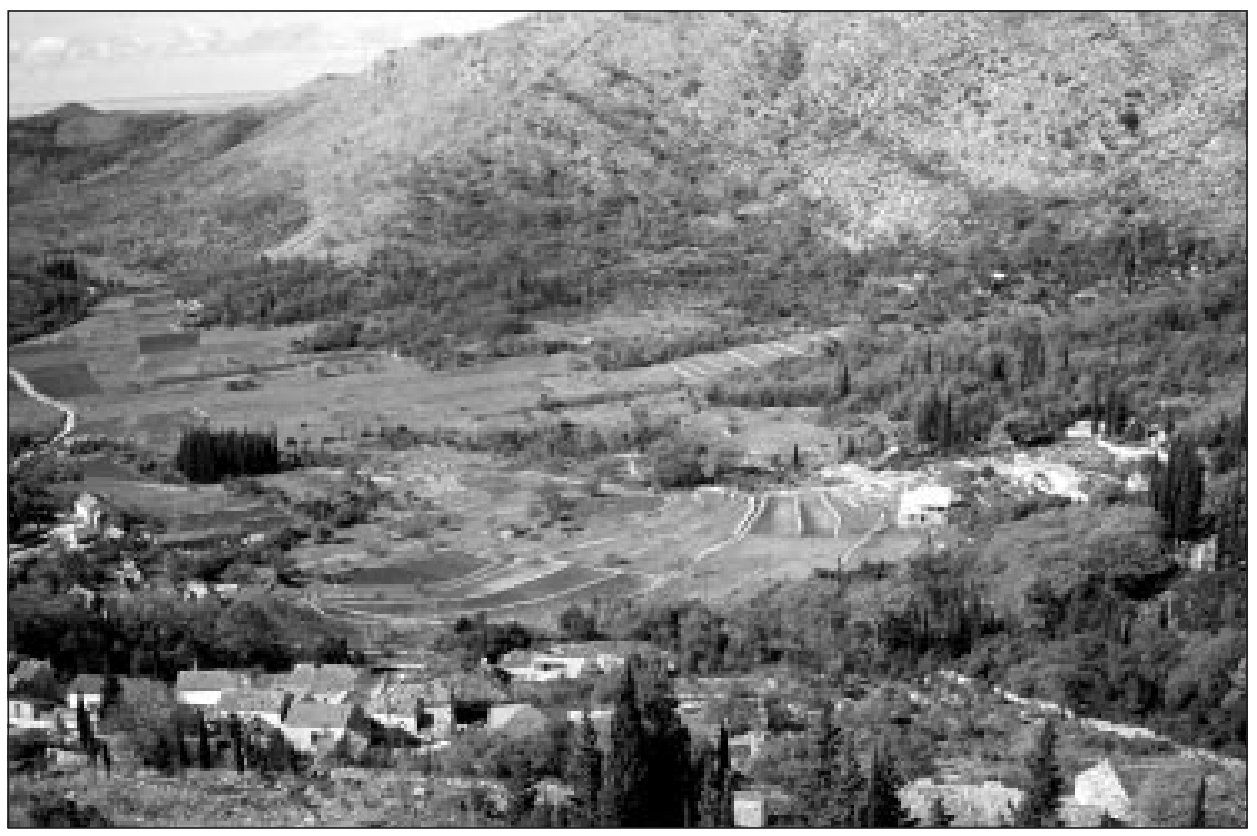

Photo 6: Ljubač karst field. Situated at a high altitude, Ljubač displays specific topography of a karst depression, with picturesque hamlets situated on the slopes and flat bottom of the valley. The fertile, arable field is surrounded by slopes overgrown with vegetation and adorned by steep escarpments and narrow, symmetrical terraces that once belonged to now abandoned vineyards (2001).

3. The third type is a karst field with arable land. The fields are situated in the zone of elongated valley depressions, with a road cutting through the middle, influencing the development and structure of the fields. Arable plots usually stretch perpendicularly towards the road, formed as a symmetrical rectangular network.

4. The fourth type of karst cultural landscape is hollows on the southern slopes of the islands Brač and Hvar and the Pelješac peninsula. They come as elongated stretches or plains, depending on the soil type and topography (Photo. 7). 


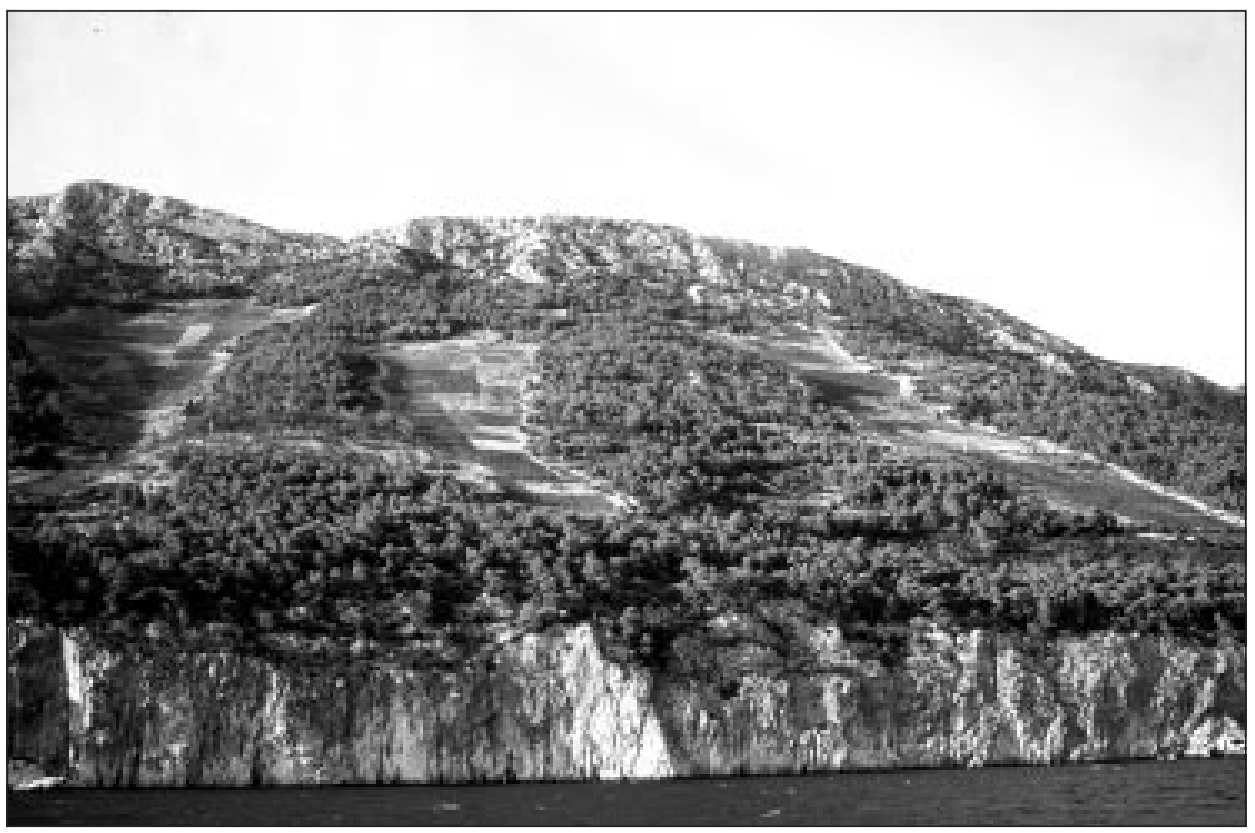

Photo 7: Southern slopes of the island of Hvar. Picturesque landscape filled with contrasts. It is specific for its steep slants, leaning up to 50 per cent, situated within drainage depressions and made of gravel detritus and similar material. Due to its porosity, they are not prone to erosion and are therefore suitable for grape growing. Such surfaces are more resistant to technological changes caused by soil cultivation, and are able to maintain their original forms longer (2001).

5. The fifth landscape type is made of terraced drystone walls. These were created on karst slopes with 6-20 degrees inclination. Stone was gathered and piled along the slopes in the form of escarpments in order to form terraces. They come in a) symmetrical and b) asymmetrical shapes. Asymmetrical terraces can be found on moderate slopes (Photo. 8), suited suitable for growing fruit trees (fig, olive, carob-tree, citruses, etc.). The trees grow far apart and planting in regular straight rows is not required, which allows for rock outcrops to remain untouched in the ground. This results in smaller planting plots, with semicircular, fairly short escarpments at the foothills (Photo. 9).

The largest influence and the most widespread changes in karst came from the construction of terraces with escarpments for planting grapevines. Stone was arranged in the upward direction, and terraces were filled by earth gathered in situ or ex situ. Escarpment height and width are proportionate to the inclination and volume of earth gathered. The most peculiar shape of terraces can be found on the islands, formed as equal narrow stretches going upward parallel to the slope 
Branka Aničić \& Dražen Perica: Structural Features of Cultural Landscape in the Karst Area (landscape in transition)

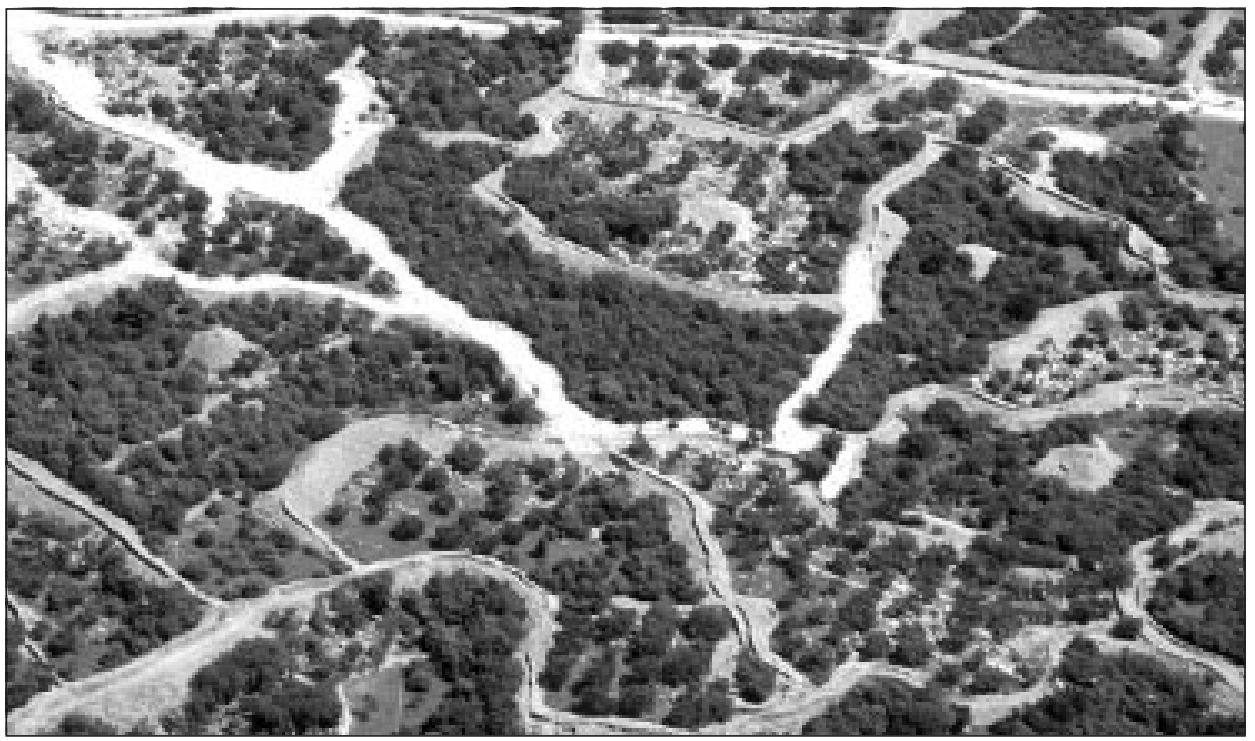

Photo 8: Krk. This, and similar landscapes, were created on mild slopes with thick, quality soil. Heaps of stone of various widths and asymmetrical lines are disappearing today, because stone is crushed and transported away for other activities, which leads to gradual but permanent loss of this characteristic landscape (2002).

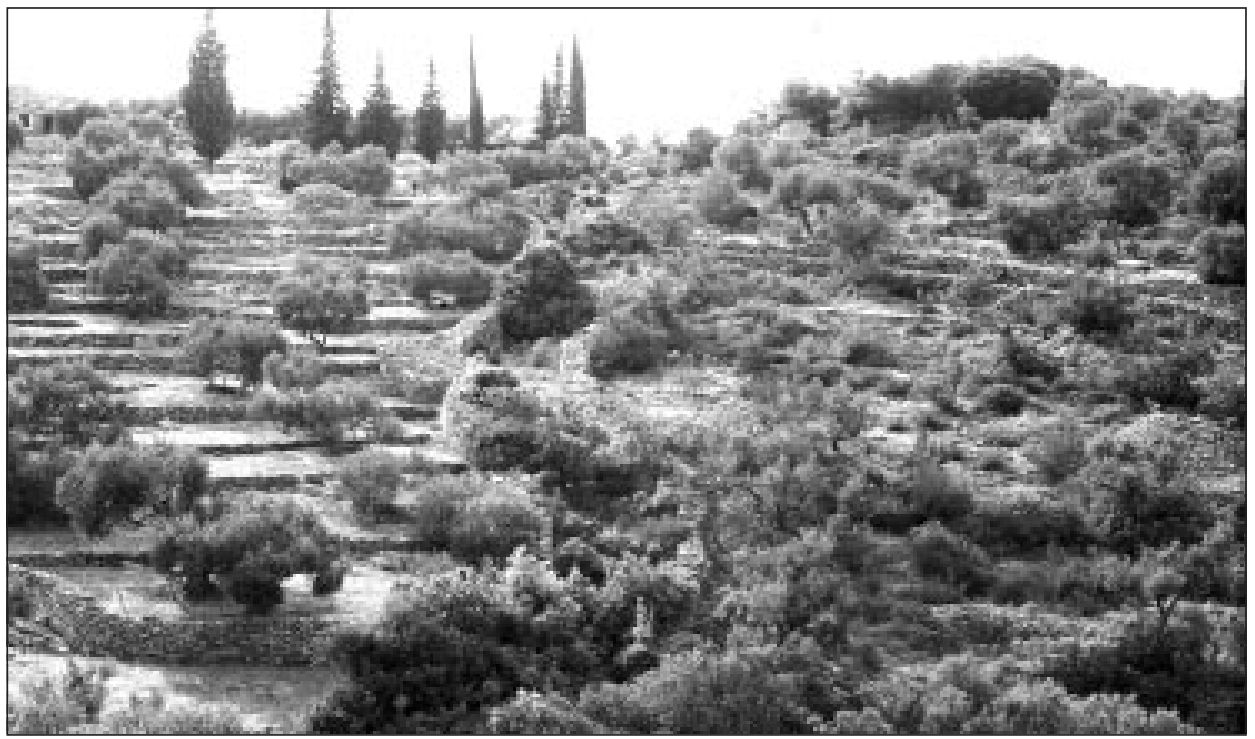

Photo 9: Brač. This landscape type is characterised by asymmetrical terraces which for centuries served as olive groves, and their individual remnants still bear witness to the irreplaceable culture of traditional utilitarian Mediterranean landscape. 


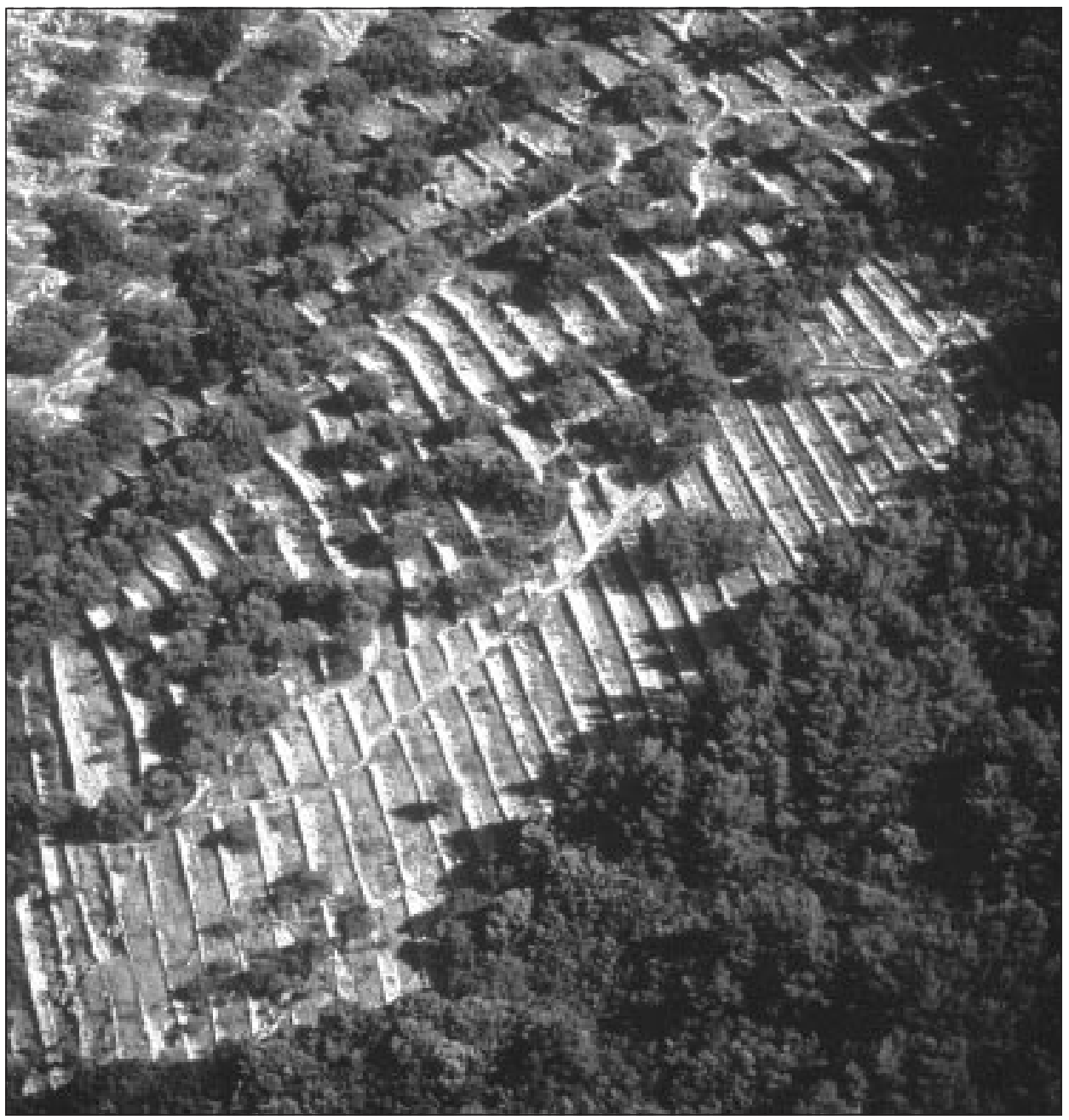

Photo 10: Cultural terraced landscape on the island of Hvar. Inaccessible, steep terraces, unique example of superhuman farming efforts and pains, are left to erosion and complete overgrowth.

(Photo. 10 and 11). However, there are terraces created on the slope of $20^{\circ}$ and more, where escarpments are compact, and some even supported by a solid rock, therefore distances between them vary. On lower level terrain, with predominant karst surfaces, terraces are predominantly rectangular, with escarpments coupled by transversal partitions and larger heaps of stone (gomilas and varvakanas) (Photo. 12 and 13).

This brief overview testifies to the remarkable diversity of landscape types that has developed in these poor, stringent living conditions. As such they certainly present an important contribution to the cultural heritage, and any efforts to preserve them would be well deserved. 


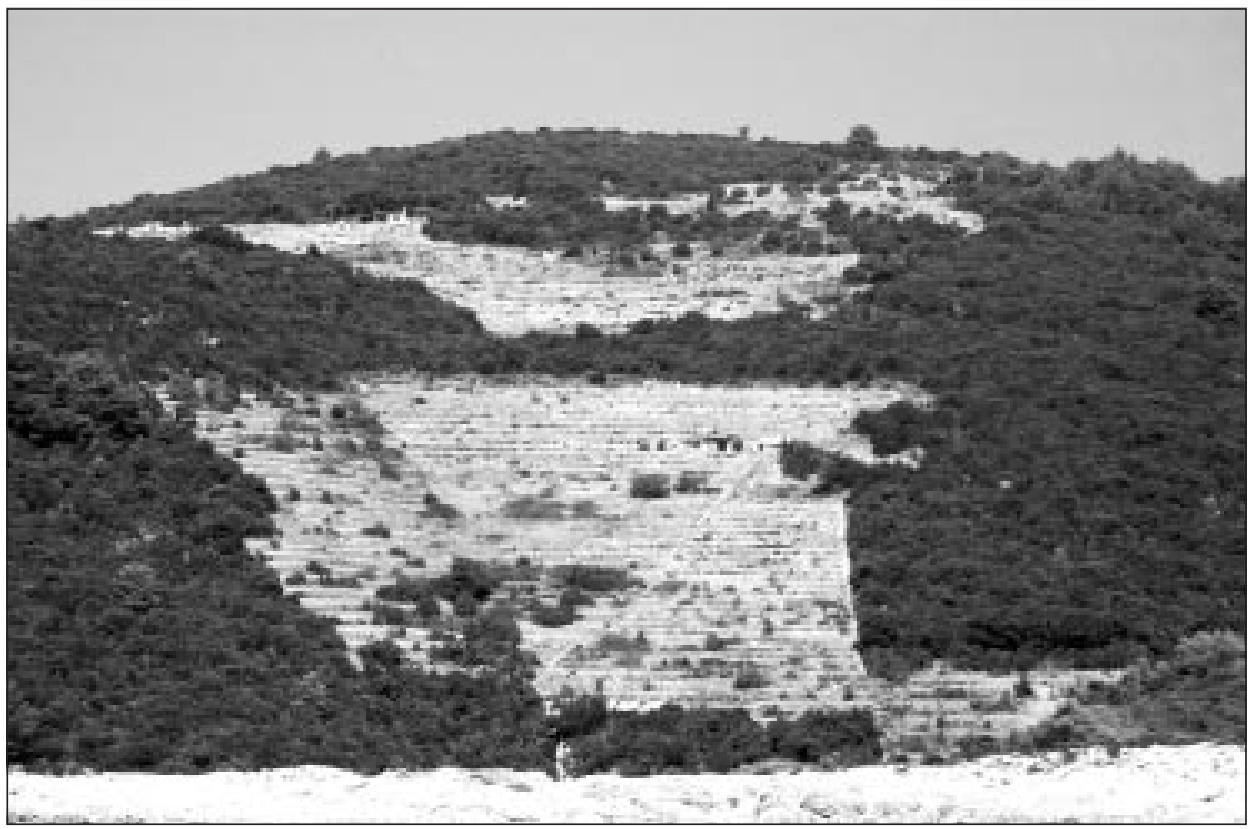

Photo 11: Cultural terraced landscape on the island of Korčula. Terraces with escarpments created on slopes are symmetrically formed stretches, following the topography. Width of terraces varies depending on the inclination, and plots are fragmented by regular or alternating transversal lines, made of drystone walls or asymmetrical heaps of stone, thus creating small rectangular plots of various sizes. Abandoned plots are overgrown by maquis and pine. The vicinity of settlements, new incentives, and the trend of switching back to grape growing and wine making, bring these and similar areas back to life (2002).

\section{LANDSCAPE IN TRANSFORMATION AND ITS PROTECTION}

The landscape of the Mediterranean basin has been created and transformed through centuries exclusively through human influence. Compared to other European regions undergoing same processes, this region has experienced far more intensive and more variable human activity, which is still noticeable in the landscape. The Mediterranean area harbours numerous diverse karst regions. Their natural character depends as much on water supply and the climate varying from mild, moist winters to dry, hot summers, as on distinctive relief variations. As Nicod and Sauro have pointed out, the most dynamic and complex section of this area can be found in the Adriatic Megaregion of Croatia (Nicod \& Sauro 1993).

The first evident changes in this area took place during Illyric in the $2^{\text {nd }}$ century $\mathrm{BC}$, and were continued at the time of Slavic invasion in the second half of the first millennium. Known as herdsmen and nomads, they were cutting down the forest, clearing the maquis and removing stones, thus creating pastures. These were the first changes of landscape, from natural forest into 


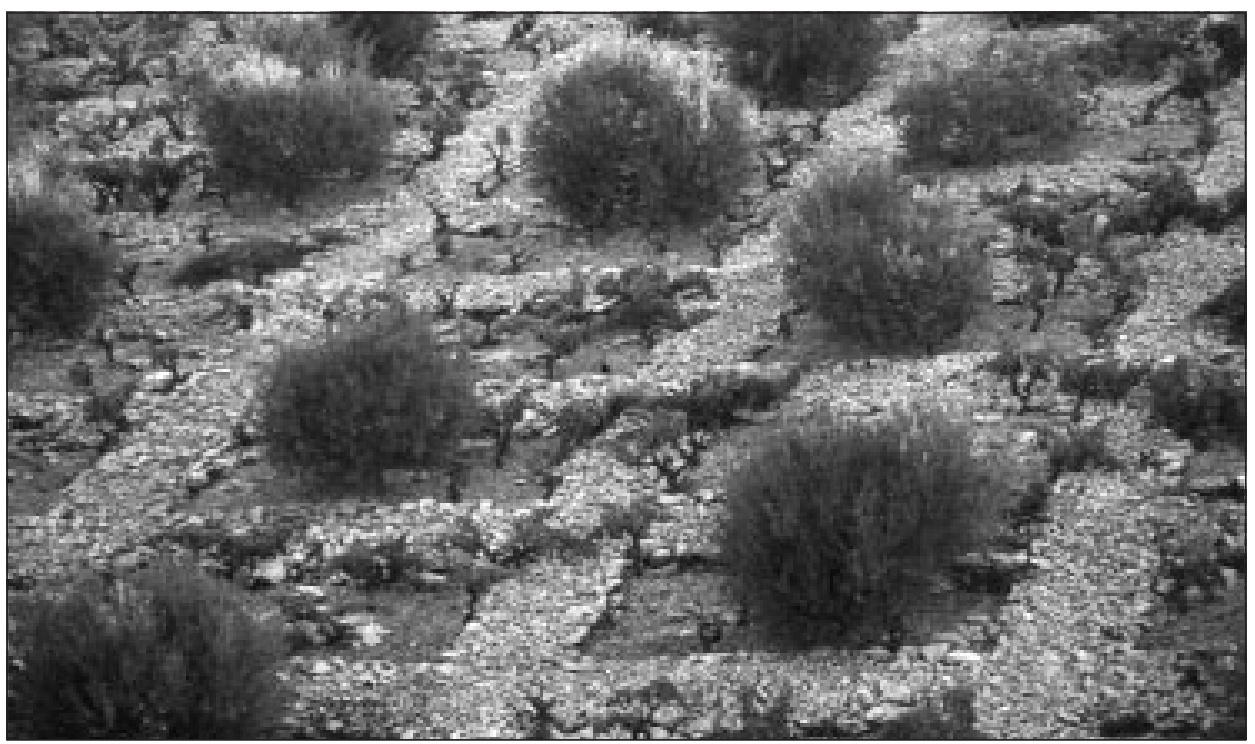

Photo 12: Internal geometrical structure of characteristic fields around Primošten is very complex. It is made of a symmetrical screen of drystone walls, circled by small arable plots which were primarily adapted to grapevine growing. Today, without road access or the use of machinery, grape growing is being abandoned, and olive becomes the main culture (2000).

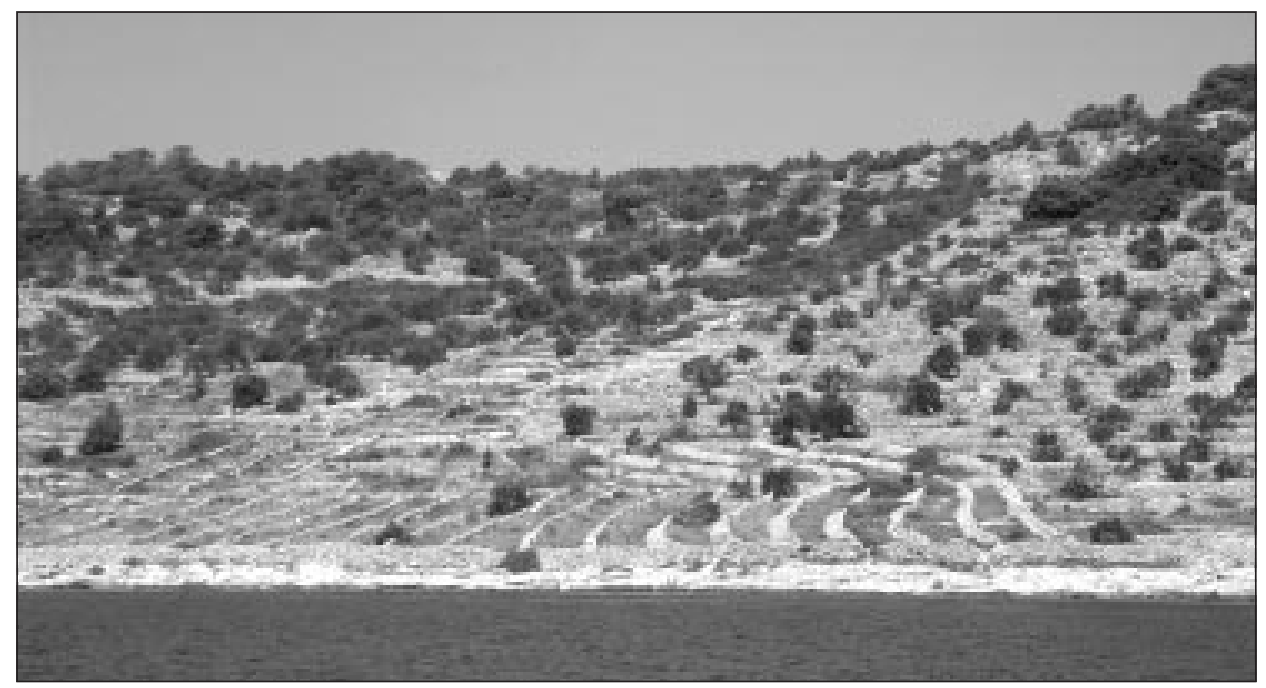

Photo 13: Kakan. Abandoned, unpopulated island; once the entire island was arable land. Its entire surface is intersected by drystone walls of various symmetrical and asymmetric shapes, various heights and widths. Climate and soil conditions were favourable for agriculture, which is visible from the remains of olive groves and drystone walls along the entire coast, almost reaching the sea (2001). 
open cultivated pastureland. More intensive felling was done during the ancient Roman period, which was continued proportionally to population growth. The impact of forest burning and felling, coupled with erosion and inadequate soil fertility, was at its peak in the mid $19^{\text {th }}$ century. Such a situation hindered the self-restoration of forest vegetation. At the same time, it has enabled the evolution of traditional karst cultural landscape, based on the high degree of integration of various uses - agricultural and residential - with natural landscape conditions. The tools used were the ones causing least harm to the landscape and its natural resources, and yielding optimal economic and other results, at the same time preserving the balance of landscape development dynamics.

Almost two millennia of stone gathering have enabled creation of arable land on the karst surface. Before the Middle Ages, the pastureland was dominant, after which until the $17^{\text {th }}$ century the major economic branch, along with livestock breeding (sheep and goat, but also pigs and cattle) was farming (cultivation of farm crops, olives and vine). In this very period of significant structural changes of cultural karst landscape, pasture and meadow plots were separated by partitions (Fig. 1), along with an increased need for expanding arable plots and more intensive grapevine growing. Slopes were being taken for private possession, and new escarpments and terraces built on them, which added to the creation of a hugely complex and culturally significant landscape (Gams 1987; Julian \& Nicod 1989; Sauro 1987). The second blooming of intensive vineyard-oriented soil cultivation and creation of new terraces took place in the mid $19^{\text {th }}$ century, and lasted up until the occurrence of phylloxera in 1909 (Encyclopaedia 1973). At the time, what were not arable plots, was covered by degraded karst - mostly bare and ecologically poor landscape. More intensive attempts of forest restoration were slow, hindered not only by natural conditions, but also by agricultural expansion. Searching for a solution through reforestation, in the second half of $19^{\text {th }}$ century certain non-indigenous species were introduced in the area, such as - black pine (Pinus nigra) and Aleppo pine (Pinus halepensis) (Horvat 1951). These fast-growing species, adaptable to limestone land and resistant to high summer temperatures, have taken root, whereas native holly-oak forests (Orno-Quercetum ilicis) almost completely disappeared.

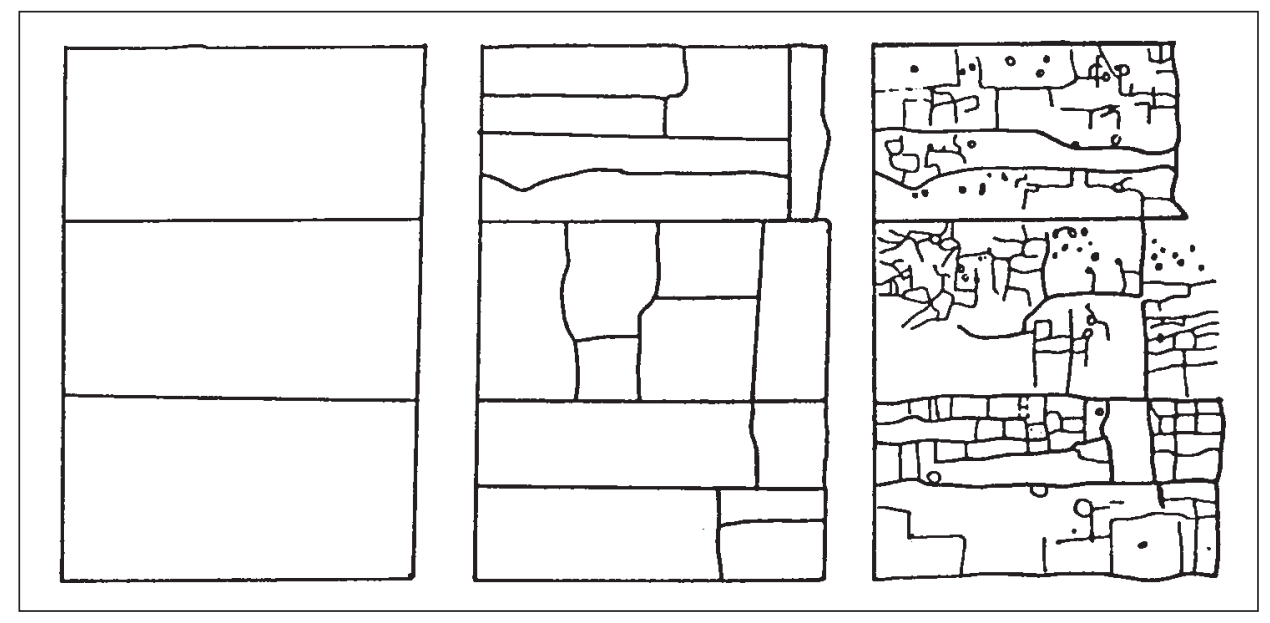

Fig. 1: Schematic development of wall pattern (Gams 1993, p.89). 
Karst cultural landscape is a manifestation of a long-lasting materialised relationship of man and nature, where each change in socio-economic circumstances has a direct impact on the environment based on economic, cultural and technological progress, the social system is changing causing also transformations in spatial organisation. These changes were once slow-progressing, but now they are faster and more radical, whereas natural adjustments, on the other hand, remain slow.

Socio-economic processes of the post-war period have triggered depopulation of large regions in the entire Mediterranean. Rural areas of the islands and the coast share the same fate, reflected in the abandonment of cultivated land, more or less together with the abandonment of settlements. The consequence of such trends is uncontrolled self-rejuvenation of forests, erosion, deterioration of very old terraces, which all contributed to overall cultural and sometimes even ecological deterioration of karst landscape.

Today, tourism is an extremely prominent activity in this area. However, it is also considered as the most questionable one in the Mediterranean landscape. Tourism is an ambitious consumer of natural resources, showing its special interest in the most attractive parts of landscape, including agricultural land. Tourism is spreading at an unstoppable pace, extensively taking up land and following a linear pattern along the entire seacoast. Its extention is opening distinct environmental conflicts, causing even wider changes in space (Barisel 1969).

Spreading of new residential development around old Mediterranean settlements is changing the traditional balanced karst agricultural landscape. Conflicting with the space, construction of illegal weekend-settlements, metal, petrochemical, and shipbuilding industrial complexes and energy facilities, seriously threatens the area.

Compared with an inherited, harmonised relationship of the environment and agriculture, the observed evolution along the coast has twofold effects. On one hand, development of certain parts of the coastal area is quickly and irrevocably changing the traditional karst landscape into an urban one, with constant presence of further construction. On the other hand, agriculture and other traditional activities are abandoned, leaving the previously occupied areas to natural succession and erosion, which permanently deprives the area of its cultural character (Photo. 14). In such circumstances, devastating forest fires become ever more frequent and far-reaching. Recently, forest fires occur on abandoned, uncultivated areas covered by underbrush, grass and medicinal plants, which dry up in summer and easily catch fire. These processes are a direct consequence of the absence of man and of soil cultivation. As fires are most frequent in summer heat, they tend to spread quickly into forests and present a severe hazard also for human settlements. Damage of livelihood resources caused by erosion and fires, mostly endangers the quality of life of the local population. A devastated landscape is equally, although indirectly, unfavourable for tourism. Of all adaptation mechanisms used by humans, cultural adaptation (in the sense of achieving balanced, harmonious relations) carries the most weight. Nowadays, physical planning emerges as a direct and effective means towards the preferred harmony (Odum 1971).

Optimal management in the sensitive Mediterranean area can be achieved primarily with the help of certain planning procedures that emphasise the features of a particular landscape, its contents, patterns, and possible land-use evaluation, which is normally in line with justified, anticipated social requirements or interests, and can be incorporated in any physical planning form (Marušić 2001). It is a framework that requires a well-prepared basis for defining and singling out valuable karst landscapes (primarily belonging to the category of traditional cultural landscape, 


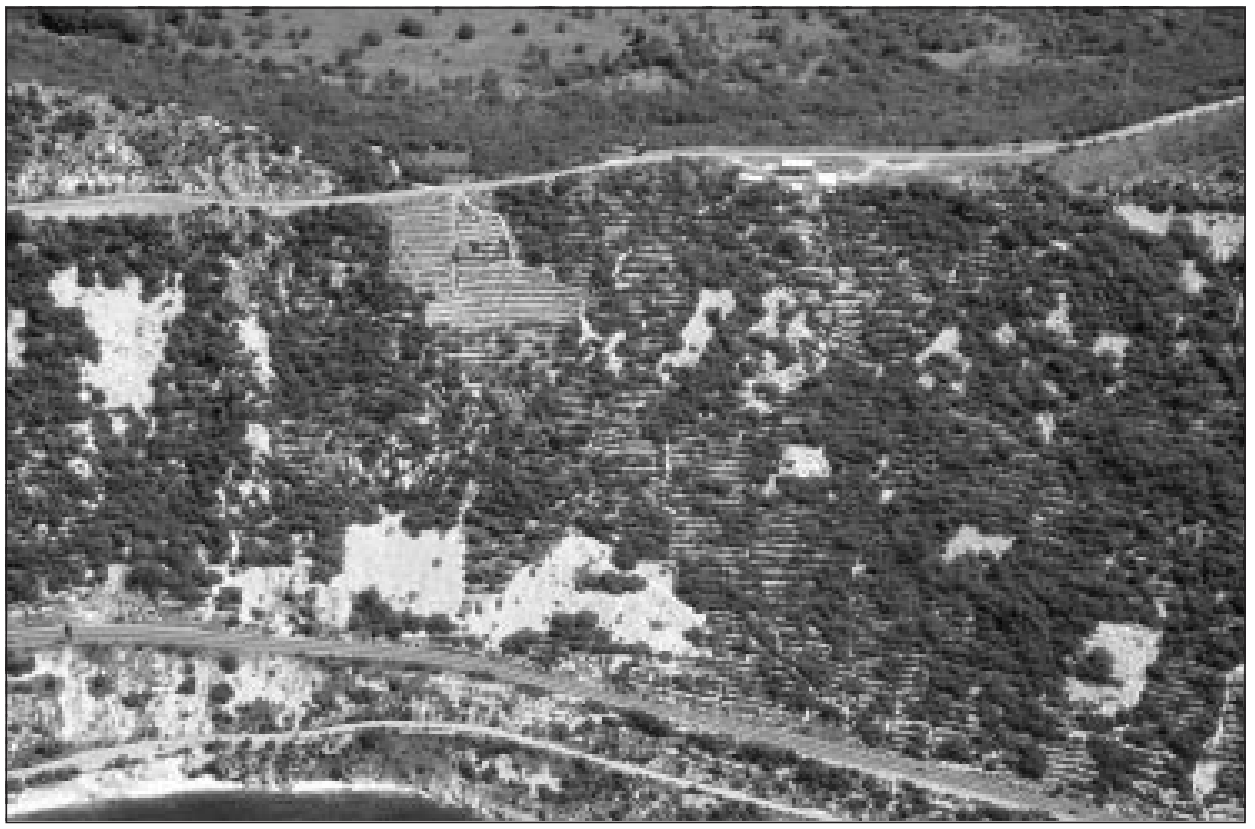

Photo 14: Landscape with cultural terraces and escarpments near the Bay of Bakar. Typical for very steep slopes at 50-70m altitude. When farming is discontinued escarpments in steep areas break away into a sipara, making the area unfavourable for vegetation growth (2002).

but not excluding regionally determined categories) of national importance, accompanied by the relevant protection guidelines.

Identification of valuable landscapes of Croatia and their categorisation is in progress. This will improve our comprehensive knowledge of the national landscape heritage and will serve as a valuable point of departure in making decisions about landscape protection and future land-uses (Aničić 2002).

\section{CONCLUSION}

The karst cultural landscape, especially on islands, is a unique manifestation of cultural heritage in the Mediterranean region and even in Europe. Social and economic changes have generated a situation in which the survival of this land as a cultural landscape becomes hardly possible. In the past, this area has been ecologically impoverished, hence current trends towards renaturalisation through succession can be seen as a positive process. Renaturation of certain natural entities will add to the value of biological and landscape diversity in the Adriatic.

On the other hand, the unique value of the these landscapes certainly calls for every effort to preserve at least a part of this heritage in its authenticity. Part of it can be restored through certain economic activities, as a result of a well-thought strategy of agricultural development, which 
should be worked out and implemented as soon as possible. Certainly, the highest ranking parts of landscape heritage that possess outstanding cultural and monumental value, and at the same time are not self-supporting, should be included in a state-supported national preservation scheme and backed by adequate material resources.

\section{REFERENCES}

Aničić, B., 2002: Idejni projekt nacionalnog programa za vrednovanje krajobraza Republike Hrvatske, Zavod za krajobraznu arhitekturu, Agronomski fakultet, Zagreb.

Barisel, A., 1969: Amenagament touristiqe du littoral, Launguedoc-Roussillon, Techniques, Architecture.

Božičević, S., 1992: Fenomen krš, Školska knjiga, Zagreb, p. 7

Encyclopaedia 1973: Poljoprivredna enciklopedija, Vinogradarstvo, Zagreb, 480- 484.

Gams, I., 1987: Karst and Man, University of Ljubljana. Study Group on Man's Impact in Karst. Proc. Int. Symposium on Hhuman Iinfluence on Karst, Postojna, Yugoslavia

Gams, I., 1991: Systems of Adapting the Littoral Dinaric Karst to Agrarian Land Use. Acta Geographica, Ljubljana

Gams, I., 1993: Human Impact on the Dinaric Karst; U: Gams, I. et al., Environmental Change and Human Impacts on the Mediterranean Karst of France, Italy and the Dinaric Region, Karst Terrains Environmental Changes and Human Impact, Catena Supplement 25, Cremplingen- Destedt, Germany, (1993), p. 83-93.

Horvat, A., 1951a: O nekim neposrednim zadacima istraživačkog rada na degradiranom kršu, Šumarski list 1-2, Zagreb. p. 4-50.

Horvat, A., 1951b: O gustoći sadnje na degradiranom kršu napose za Alepski bor, Šumarski list 8-10, Zagreb. p. 1-11.

Julian, M. \& Nicod, J., 1989: Les Karst des Alpes du Sud et de la Provence. Zeitschrift für Geomorphologie. Suppl.-Bd 75, 1-48.

Marušić, I., 2001: Landscape heritage, spatial planning and sustainable development, CEMAT Seminar Lisabon

Nicod, J. \& Sauro, U., 1993: Background to human impact on karst in the Mediteranean region; In: Games et al., Environmental Change and Human Impacts on the Mediterranean Karst of France, Italy and the Dinaric Region, Karst Terrains Environmental Changes and Human Impact, Catena Supplement 25, Cremplingen-Destedt, Germany, 59-83.

Odum, P.E., 1971: Fundamentals of ecology, W.B. Sunders Company Philadelphia, London, Toronto.

Sauro, U., 1987: The impact of man in the karstic environments of the Venetian Prealps, Karst and Man, University of Ljubljana. Study Group on Man's impact in Karst. Proc. Int. Symposium on human influence on Karst, Postojna, Yugoslavia, p. 241-253.

Photography credits:

Photographs: Branka Aničić (1,3,5,6,7,8,11,12,13,14); Zofija Mavar (2); D. Perica (9).

Photographs (4,10) from the Archives of the Landscape Architecture Institute, Faculty of Agriculture University of Zagreb. 